\title{
NUP98/HOXD11 Fusion Gene
}

National Cancer Institute

\section{Source}

National Cancer Institute. NUP98/HOXD11 Fusion Gene. NCI Thesaurus. Code C99449.

A fusion gene that results from a chromosomal translocation $\mathrm{t}(2 ; 11)(\mathrm{q} 31 ; \mathrm{p} 15)$ which fuses the first half of the NUP98 gene with the 3' part of the HOXD11 gene. This rearrangement is associated with acute myeloid leukemia. 